\title{
The Enya mounds: a lost mound-drift competition
}

\author{
D. Van Rooij · V. A. I. Huvenne - D. Blamart · J.-P. Henriet · \\ A. Wheeler · H. de Haas
}

Received: 6 March 2007/Accepted: 14 December 2007/Published online: 3 January 2008

(C) Springer-Verlag 2007

\begin{abstract}
The genesis and evolution of cold-water coral banks along the Northeastern Atlantic margin is known to be influenced by several factors, among which the palaeotopography and nature of the coral settling surface, the presence of bottom currents and sediment supply. In this paper, a case study is presented of the Enya mound cluster, located in the southernmost tip of the Belgica mound province, west of Ireland. Below this mound cluster, seismic stratigraphy revealed a yet unmapped local unconformity RD1b, being part of a composite erosion event (RD1). As such, from the Late Miocene to Late Pliocene, at least two erosional events have incised the margin, ending with the final RD1a "moundbase" unconformity, acting as a base for the Enya mounds. During the
\end{abstract}

D. Van Rooij ( $\square)$ · J.-P.Henriet

Renard Centre of Marine Geology, Ghent University,

Krijgslaan 281 S8, 9000 Ghent, Belgium

e-mail: david.vanrooij@ugent.be

URL: http://www.rcmg.ugent.be

D. Van Rooij · D. Blamart

Laboratoire des Sciences de Climat et de l'Environnement (LSCE/IPSL/UVSQ), Laboratoire mixte CNRS/CEA, Bâtiment

12, 4 avenue de la Terrasse, 91198 Gif-sur-Yvette, France

V. A. I. Huvenne

Geology and Geophysics Group,

National Oceanography Centre, Southampton, European Way, Southampton SO14 3ZH, UK
A. Wheeler
Department of Geology and Environmental Research Institute, University College Cork, College Rd., Cork, Ireland
H. de Haas
Royal Netherlands Institute for Sea Research (NIOZ),
PO Box 59, 1790 AB Den Burg, The Netherlands

Quaternary the mounds became outgrown and were covered by a mounded contourite drift. In addition, they are closely associated with a cluster of seabed pockmarks. The bottom current regime which became active since the Middle Pleistocene has certainly influenced the fate of this mound cluster. The occurrence of the pockmarks seems to be related to relatively recent fluid migration processes, however leaving an open question if any previous seepage phases were involved in the growth or initiation of the coral banks.

Keywords Cold-water coral banks - Contourite drift . Pockmarks · Unconformity - Seismic stratigraphy

\section{Introduction}

At several locations along the deep-water NW European margin, provinces of cold-water coral banks are found within specific hydrographic and morphologic conditions (De Mol et al. 2002; Lindberg et al. 2007; Mienis et al. 2006; Wheeler et al. 2007). Most of the time, they are located near steep parts of the margin on hardgrounds or irregular unconformities in the (sub)surface. These environmental factors make sites attractive for cold-water coral settling and growth, implying that benthic currents and a suitable settling ground are intrinsic to the genesis and growth of the mounds. The bottom currents are expressed in the surrounding sediments by sand ripples on a small scale (Foubert et al. 2005; Wheeler et al. 2007), or sediment (contourite) drifts on a larger scale (Huvenne et al. 2007; Kenyon et al. 2003; Van Rooij et al. 2007a). Exactly the combination of the sedimentary input and the hydrodynamic regime are considered to be key to the size of the coral banks and the density of an entire province (De Mol 
et al. 2005; Kenyon et al. 2003; O'Reilly et al. 2003). A stronger current regime, limiting nutrient availability, might explain the lower density of the SE Rockall Trough Pelagia mounds. A combination of higher sedimentation rates and more sluggish currents could be responsible for the partial burial of the Belgica mounds (Van Rooij et al. 2003) and the complete burial of the Magellan mounds (Huvenne et al. 2007), while the SW Rockall Trough Logachev mounds are preserved due to relatively low sedimentation rates (Mienis et al. 2006; van Weering et al. 2003).

On the other hand, an enigmatic association has been suggested between the presence of coral banks and hydrocarbon seepage. Several potential mechanisms have been described where the initiation phases of coral banks are not only controlled by environmental factors, but also through the mediation of hydrocarbon seepage (Henriet et al. 1998; Henriet et al. 2001; Hovland and Risk 2003; Naeth et al. 2005). According to Hovland et al. (1994) the large coral banks located on the northern slope of the Porcupine basin (since then named "Hovland mounds") are directly connected with Jurassic hydrocarbon reservoirs through faults. Henriet et al. (2001) suggested a short-lived 'triggering' control of the Magellan mound nucleation, related to episodic fluid venting of these underlying reservoirs or to the interglacial destabilization of gas hydrate layers, followed by relaying growth controls, probably from external fluxes. Such a hydrocarbon leakage from Jurassic reservoirs towards the Belgica mound province was considered possible by Naeth et al. (2005) through modelling of fluid migration pathways. Although the origin of the Darwin mounds also is related to fluid escape (porewater) and pockmarks (Masson et al. 2003), it is clear that fluid escape alone is not sufficient to support coral colonies. As such, no evidence for the presence of any directly associated seepage has been found near coral banks on the Rockall Trough margins or in the Porcupine Seabight (Bailey et al. 2003; De Mol et al. 2007; Huvenne et al. 2003; Kenyon et al. 2003; Mienis et al. 2006; Shannon et al. 2007).

In this paper we describe a cluster of buried mounds, which we name the "Enya" mounds, located at the southernmost extremity of the Belgica mound province (Figs. 1,2). Despite their relatively small size, they are closely associated with a contourite drift. We will discuss the possible timing, origin, evolution and burial of these mounds with regard to the local environmental settings and the known regional development of adjacent mound provinces. Moreover, the location of a field of pockmarks shows an intriguing association with the Enya mound cluster. Possible scenarios concerning the timing and origin of these seepage features will be presented and discussed.

\section{Regional setting}

Geology and morphology

The Porcupine Seabight is a shallow to deep-water, amphitheatre-shaped basin southwest of Ireland, forming a small bight along the North Atlantic margin (Fig. 1). The geological evolution of the basin has been extensively described by Croker and Shannon (1995), Shannon (1991) and Shannon et al. (2007); the Porcupine Seabight is the surface expression of the underlying deep sedimentary Porcupine Basin, which is a failed rift of the proto-North Atlantic Ocean, filled in with a $10 \mathrm{~km}$ thick series of Mesozoic and Cenozoic sediments. The Cenozoic sedimentary succession of the basin has been cut by several major unconformities which can be correlated with the Rockall Basin. These Cenozoic palaeoceanographic events played a major role in the shaping of the present-day margin and in the creation of a geological and environmental template capable of hosting coral bank settling

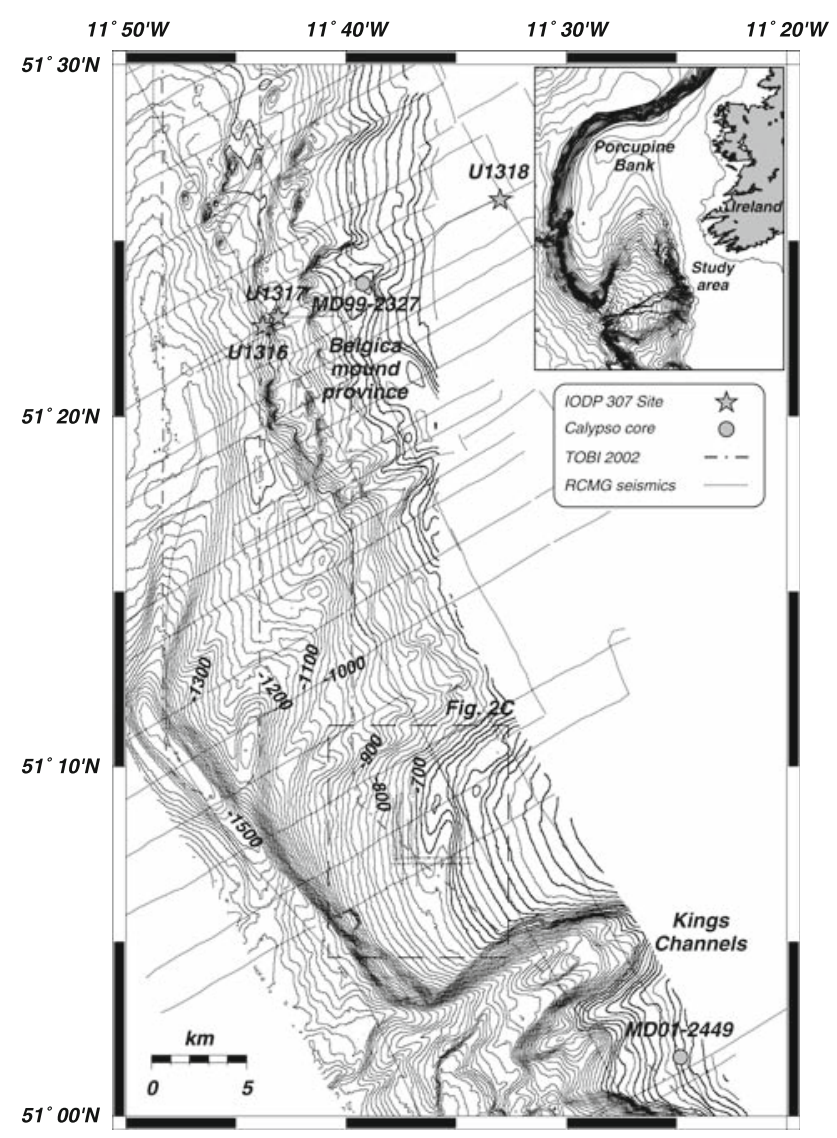

Fig. 1 Location map of the study area with respect to the Belgica mound province. The location of $\mathrm{R} / \mathrm{V}$ Marion Dufresne Calypso cores, IODP 307 sites, R/V Pelagia TOBI track and the RCMG seismic profiles are overlain on AWI Bremerhaven multibeam bathymetry with a contour interval of $20 \mathrm{~m}$ (Beyer et al. 2003) 
(McDonnell and Shannon 2001; Shannon et al. 2007; Stoker et al. 2005; Van Rooij et al. 2007a).

A first major unconformity C30 (latest Eocene to earliest Oligocene) coincides with the onset of contourite drift deposition and marks the change from predominantly downslope sediment transport to mainly along-slope sediment movement. From latest Eocene times the Porcupine and Rockall basins developed into undersupplied deepwater basins through differential basin subsidence (Shannon et al. 2007). McDonnell and Shannon (2001) tied a set of unconformities (C20 series), of late Early Miocene to early Mid-Miocene age, to a major plate reorganization and the last pulses of the Alpine Orogeny. Within the Belgica mound province, this unconformity was recognized by Van Rooij et al. (2003) as the local RD2 unconformity. The C10 Early Pliocene unconformity was observed by Stoker et al. (2001) along the entire length of the Northwest European Atlantic margin, and developed as a result of the onset of global cooling and Northern European glaciation. McDonnell and Shannon (2001) correlated this with an unconformity of similar character in the Porcupine Basin, although De Mol et al. (2002) and Van Rooij et al. (2003) suggested an intra-Pliocene age for the locally equivalent RD1 unconformity in the Belgica mound province.

Recently, new data from IODP 307 Sites U1318 and U1316 (Fig. 1) have shed new light on the timing of the RD1 unconformity (IODP 307 Expedition Scientists 2005). A palynostratigraphic study of the upper slope site U1318 (Fig. 1) proposes an earliest Late Miocene age (10.5 Ma) for the upper boundary of the underlying unit (Louwye et al. 2008), while Sr stable isotope stratigraphy provided, on the other hand, a youngest age of $8.96 \mathrm{Ma}$ (Kano et al. 2007). Due to the discrepancy in dates, the onset of the RD1 erosion event can be only be attributed a general Late Miocene age. The unit above this unconformity was dated by Kano et al. (2007), providing an oldest age of $1.24 \mathrm{Ma}$ at site U1318, whereas in the downslope located site U1316 (Fig. 1), the base of a coral bank was dated at 2.6 Ma. These data infer the RD1 unconformity represents a 6.6 to 8.2 Ma long hiatus between the Late Miocene and the Late Pliocene. The dramatic palaeotopography created by this large-scale erosional event on the eastern slope of the Porcupine Seabight, and the hydrodynamic regime enforced by it, created an attractive environment for successful coral colonization by the Late Pliocene (as documented on IODP site U1316). However, the (clastic) drift sedimentation around the mounds is estimated to have started only from the middle Early Pleistocene onwards (Kano et al. 2007; Van Rooij et al. 2007a).

During the Quaternary, the main sediment supply zone for the Porcupine Seabight was located on the Irish and Celtic shelves, while the input from the Porcupine Bank seems to be rather limited (Rice et al., 1991). In contrast to the slopes of the Celtic and Armorican margins, which are located east of the Porcupine Seabight, only one major sediment-supplying channel system is present on the southern margin of the Seabight (Beyer et al. 2007; Kenyon et al. 1978; Wheeler et al. 2003). This east-west oriented Gollum Channel System is thought to be the downstream component of a large fluvial system, which extended from the southern Irish Mainland Shelf during glacial periods. Rice et al. (1991) and Wheeler et al. (2003) suggest that the present-day channels are inactive.

The geological template of this area has created two distinct morphologic environments along the eastern slope of the Porcupine Seabight (Fig. 2a). North of $51^{\circ} 12^{\prime} N$, the large-scale morphology of the Belgica mound province is still dominated by the fingerprint of the RD1 palaeotopography and by the N-S aligned coral banks (Beyer et al. 2007; Van Rooij et al. 2003). The latter are associated with small turbiditic gullies, although the main sedimentary environment is dominated by alongslope processes. South of $51^{\circ} 12^{\prime} \mathrm{N}$, the Kings and Gollum Channels can be recognized where respectively broad channels (north) and canyons (south) cross-cut a rather smooth slope (Fig. 2a) (Beyer et al. 2007; Van Rooij 2004). This smooth slope can be seen as the "interfluvia" of the channels, mainly collecting the fine-grained suspended sediment load which is transported towards the channels during glacial periods.

\section{Hydrography}

A complete review of the hydrography of the coral bank provinces near the Porcupine Seabight is given by White (2007). The water mass stratification contains three main components. Within the upper $700 \mathrm{~m}$, the warm and saline Eastern North Atlantic Water (ENAW) is carried northwards along the NE Atlantic margin by the Shelf-Edge Current (SEC) (New et al. 2001; Rice et al. 1991; White 2007). Below, Hargreaves (1984) recognized the Mediterranean Outflow Water (MOW), which is observed down to $1,200 \mathrm{~m}$. It has a varying influence on the upper layer water masses through deep convective mixing in winter months. According to New et al. (2001), the poleward spreading of the MOW occurs in a reasonably steady boundary undercurrent from the Gulf of Cadiz, as far as the Porcupine Seabight. The deeper water below the MOW contains Labrador Sea Water from 1,200 to 1,800 m and North East Atlantic Deep Water with contributions of Norwegian Sea Water from $1,900 \mathrm{~m}$ onwards.

Along the eastern slope of the Porcupine Seabight, especially within the Belgica mound province but also near the Enya mounds, the hydrodynamic environment seems influenced by the presence of the MOW (Van Rooij et al. 2007a; White 2007). Rice et al. (1990) reported currents 

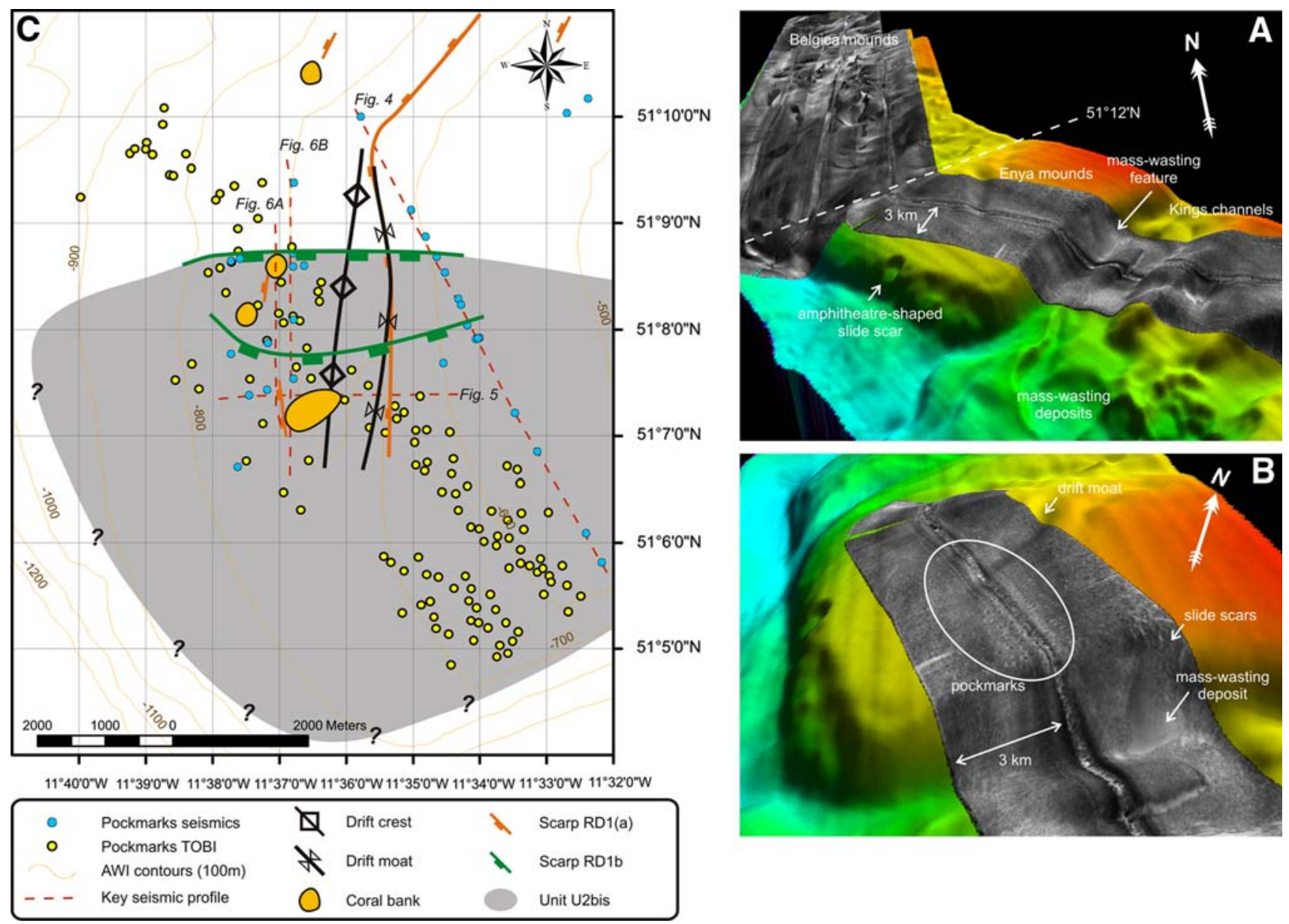

Fig. 2 a 3D morphological setting of the study area with AWI Bremerhaven multibeam bathymetry and TOBI sidescan sonar in comparison with the Belgica mound province, as shown in Fig. 1. b
3D morphological setting of the Enya area, with focus on the pockmarks and mass-wasting evidence. c Interpretation of the combined geophysical observations rarely exceeding a speed of about $15 \mathrm{~cm} \mathrm{~s}^{-1}$ at a height of $1 \mathrm{~m}$ above the seafloor. However, within the Belgica mound zone, currents are supposed to be generally greater than $15 \mathrm{~cm} \mathrm{~s}^{-1}$ for about $10 \%$ of the time (White 2007). Rice et al. (1991) have recorded strong semidiurnal to diurnal tidal variations in current speed and direction at several locations. Moreover, the closer to the seabed, the stronger the mean currents, which seem to be more persistent and alongslope, due to the topographic control. Rice et al. (1991) and De Mol et al. (2002) have indeed suggested that the condition for reflecting internal waves is met at a depth between 500 and $1,000 \mathrm{~m}$ on the eastern flank of the Seabight.

\section{Materials and methods}

The study area has been surveyed with single-channel reflection seismic profiling by R/V Belgica in 1998, 1999 and 2003 (Fig. 1). The data were acquired using a 500J
SIG surface sparker source and recorded onto a ELICS Delph 2 system through a single-channel surface streamer. In general, the standard vertical resolution of sparker data varies between 0.4 and $1 \mathrm{~m}$. The seismic data underwent a basic processing, starting with a broad-window Butterworth bandpass filter $(200 \mathrm{~Hz}$ with a $24 \mathrm{db} /$ oct slope and $2,000 \mathrm{~Hz}$ with a $36 \mathrm{db} /$ oct slope), followed by a minimum phase predictive deconvolution (with a $20 \mathrm{~ms}$ window), and a second Butterworth bandpass filter $(250 \mathrm{~Hz}$ with a $24 \mathrm{db} /$ oct slope and $700 \mathrm{~Hz}$ with a $36 \mathrm{db} /$ oct slope). All profiles also underwent swell-filtering.

Detailed multibeam bathymetric information was acquired by means of a $15.5 \mathrm{kHz}$ Hydrosweep DS-2 multibeam echosounder during the ANTXVII/4 cruise of R/V Polarstern (May-June 2000) over a 15-20 km wide strip on the eastern slope of the Porcupine Seabight. The data were processed at the AWI Bremerhaven and presented in detail by Beyer et al. (2003) and Beyer et al. (2007)

High-resolution $30 \mathrm{kHz}$ TOBI (NOC Southampton) side-scan sonar coverage was obtained during the M2002 
campaign on board of R/V Pelagia in June-July 2002 (Figs. 1,2a,b). Here, a total swath width of $6,000 \mathrm{~m}$ ( $3,000 \mathrm{~m}$ on either side) could be obtained while the instrument was towed at about $300-400 \mathrm{~m}$ above the seabed. The TOBI data were processed with the PRISM software system at NOC Southampton (Le Bas and Hühnerbach 1999) and partly discussed in Huvenne et al. (2007).

Core data from a relatively nearby Calypso core MD012449 (24.84 m long, $435 \mathrm{~m}$ water depth), which was collected by R/V Marion Dufresne in 2001, is used to characterize the local sedimentary environment (Figs. 1,3). This core was compared with core MD99-2327 from Van Rooij et al. (2007b) on the records of dry bulk (gamma) density, magnetic susceptibility, mean grainsize and $\delta^{18} \mathrm{O}$ stable isotopes. Grainsize analysis were performed every $5 \mathrm{~cm}$ using a Coulter LS130. The $\delta^{18} \mathrm{O}$ stratigraphy for this core was obtained from 10 to 20 tests of $N$. pachyderma (s.) at a sample interval of $10 \mathrm{~cm}$. However, no samples were available between 170 and $171 \mathrm{~cm}, 1,559-1609 \mathrm{~cm}$ and $1,689-1,739 \mathrm{~cm}$. The analyses were performed on a VG Optima mass spectrometer equipped with a "Kiel device" for automatic acidification of individual samples. The isotopic values are reported as per mil deviation with respect to the international V-PDB standard. The uncertainties on the isotope measurements are $0.08 \%$.

\section{Seabed morphology}

The study area is located on the northern shoulder of the Kings Channels and slopes gently $\left(2.8^{\circ}\right)$ towards the SSW (Figs. 1,2). It is bound at its southern and western side by steep slopes of $8.5^{\circ}$ to locally $11^{\circ}$. Along the edges of these abruptly steep slopes, distinct mass-wasting features (e.g. amphitheatre-shaped slide scar) can be observed (Figs. 2,4). The morphologic boundary of $51^{\circ} 12^{\prime} \mathrm{N}$ forms the northern limit, while towards the east the bathymetry steadily shallows towards the Irish mainland shelf (Fig. 2 a). Two major features interrupt the rather smooth seafloor morphology. First of all, a $4 \mathrm{~km}$ long, clearly south-north elongated moat channel of approximately $500 \mathrm{~m}$ width is observed along the $11^{\circ} 35^{\prime} \mathrm{W}$ meridian. Approximately $700 \mathrm{~m}$ west of this channel, a gentle elongate mounded morphology is observed. The topographic difference between these two features only reaches a maximum of $40 \mathrm{~m}$. Secondly, a cluster of 127 pockmarks has been observed on the sidescan sonar data (Fig. 2). Fifty of them were also recognized on the high-resolution seismic profiles and contributed in obtaining size and depth information, varying between 1 and $4 \mathrm{~m}$ (Fig. 4). They broadly form a NW-SE elongated cluster which is approximately $12 \mathrm{~km}$ long and $5.6 \mathrm{~km}$ wide (Fig. 2c). The diameter of these pockmarks ranges between 38 and $163 \mathrm{~m}$, with an average of $130 \mathrm{~m}$.

\section{Seismic stratigraphy}

The studied seismic profiles closely fit into a larger, more regional dataset (Fig. 1). This allowed not only a correlation with the existing seismic stratigraphy for the Belgica mounds (Van Rooij et al. 2007a,2003), but also with the IODP 307 sites for lithology and chronostratigraphic framework.

\section{Pre-mound stratigraphy}

The low-amplitude reflections of the lowermost unit U3 are only visible on few seismic profiles, since their depth lies close to the maximum seismic penetration depth (Fig. 5). Nevertheless, in a particular zone of the slope, one can observe the typical upslope migrating sigmoidal deposits, interpreted as a set of sediment waves (Van Rooij et al. 2003). They might very well be demonstrating the first stages of Late Oligocene to Early Miocene alongslope sediment transport in the basin as suggested by Shannon et al. (2007). The upper boundary of this unit is the slightly erosive RD2 unconformity which has been attributed a late Early Miocene to early Mid-Miocene age (Shannon et al. 2007; Van Rooij et al. 2003).

The subsequently deposited unit U2 is characterized by an acoustically nearly transparent seismic facies (Figs. 4,5). Its lithology is uniform and consists of silty clay, fine-grained sand and clayey silt with variable carbonate content between 27 and $50 \mathrm{wt} \%$ (IODP 307 Expedition Scientists 2005). Within this unit, only a few sets of gently downwards dipping, continuous, relatively high-amplitude reflectors are observed. In the studied area, this unit maintains a maximum thickness of over $200 \mathrm{~ms}$ TWT. However, towards the north, beyond the $51^{\circ} 12^{\prime} \mathrm{N}$ boundary, the thickness of this unit dramatically drops from approximately $100 \mathrm{~ms}$ TWT to $0 \mathrm{~ms}$ TWT over about $350 \mathrm{~m}$, creating relatively steep flanks of about $15^{\circ}$. Northward from this point, only remnants of this unit are found.

However, unlike in the Belgica mound province, the top of this unit shows a yet unmapped southward dipping erosional unconformity cutting into U2 (Figs. 2c,4, 5, 6). This local unconformity seems to merge with the undulating RD1 unconformity in the northern part of the study area. Hence, the RD1 event will be divided into a RD1b and RD1a unconformity. They also form the respectively lower and upper boundaries of local subunit U2bis $\left(16 \mathrm{~km}^{2}\right)$, which is present over the entire southern part of 
Fig. 3 Stratigraphic and event comparison (grey-shaded areas and dashed lines) between cores MD01-2449 and MD99-2327 with respectively a,f dry bulk density $\left(\mathrm{g} \mathrm{cm}^{-3}\right), \mathbf{b}, \mathbf{g}$ magnetic susceptibility (SI), c,h mean grainsize $(\mu \mathrm{m})$ and $\mathbf{d}, \mathbf{e}$ stable $\delta^{18} \mathrm{O}$ isotopes (\%o vs. PDB) on $N$. pachyderma $\mathrm{s}$. The correlation peak in magnetic susceptibility is considered to be HL5

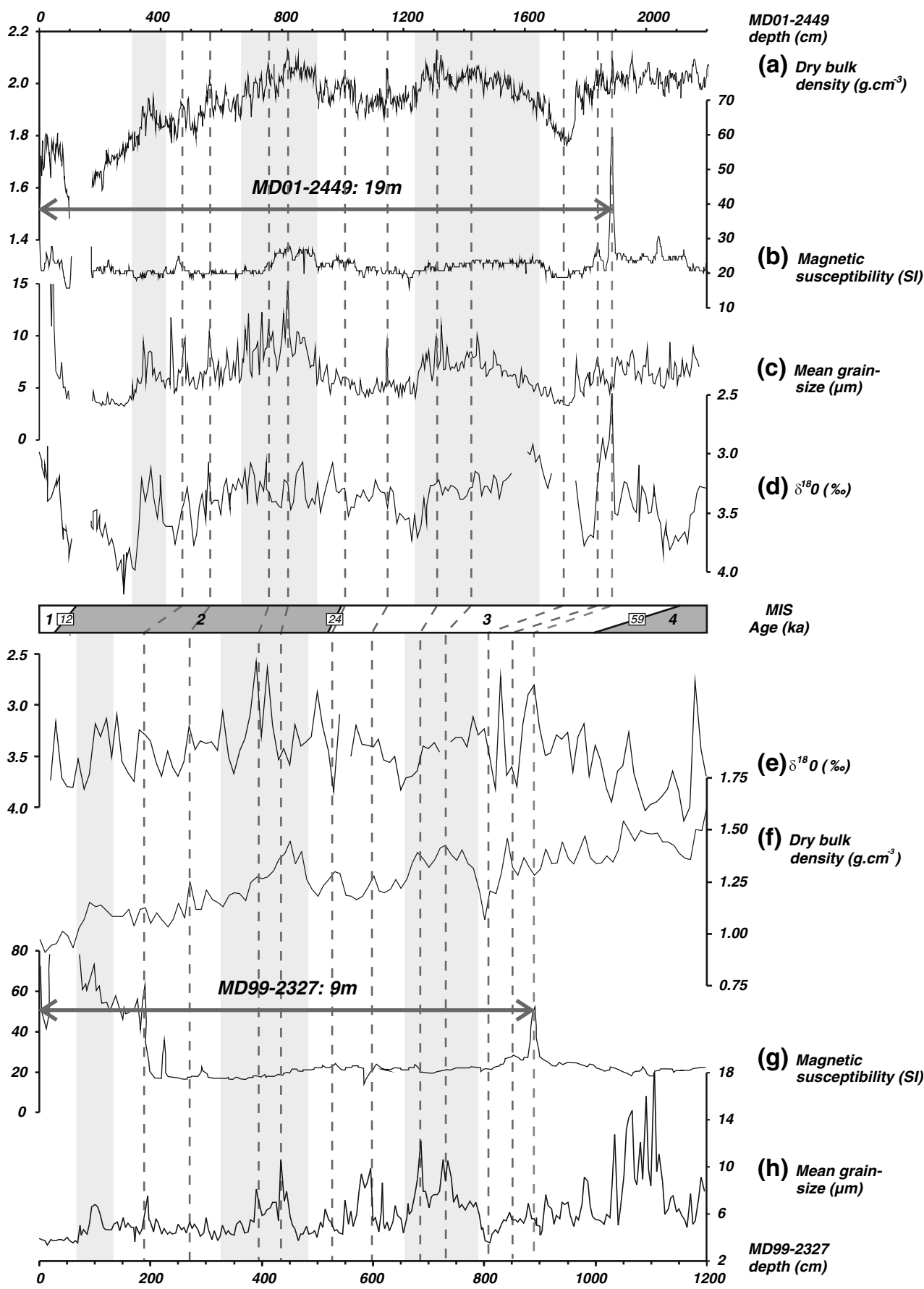

the study area (Fig. 2c). The seismic facies of U2bis is very complex. Figure 5 shows a gradual upslope fill, evolving from westward dipping undulating reflections in the west into upslope migrating downlapping sigmoidal deposits in the east (Fig. 5). On north to south oriented profiles, gently southward dipping flat to undulating reflectors, onlapping on the RD1b unconformity, can be observed (Fig. 6). However, upslope, this changes into a complex set of steeply dipping sigmoids, suggesting a high-energy depositional environment.
Setting and characteristics of the Enya mounds

The palaeotopography created by the combined RD1 unconformities created a steep $\left(13^{\circ}\right) \mathrm{S}-\mathrm{N}$ oriented scarp of U2 strata (Fig. 2c). The topographic difference of the scarp is about $150 \mathrm{~ms}$ TWT, which approximates $120 \mathrm{~m}$ (using an estimated $\mathrm{P}$-wave velocity of $1,600 \mathrm{~m} \mathrm{~s}^{-1}$ ). This steep flank can be traced over more than $6 \mathrm{~km}$. Approximately $1 \mathrm{~km}$ to the west of this scarp, a smaller topographic irregularity or scarp can be observed (Fig. 5). 

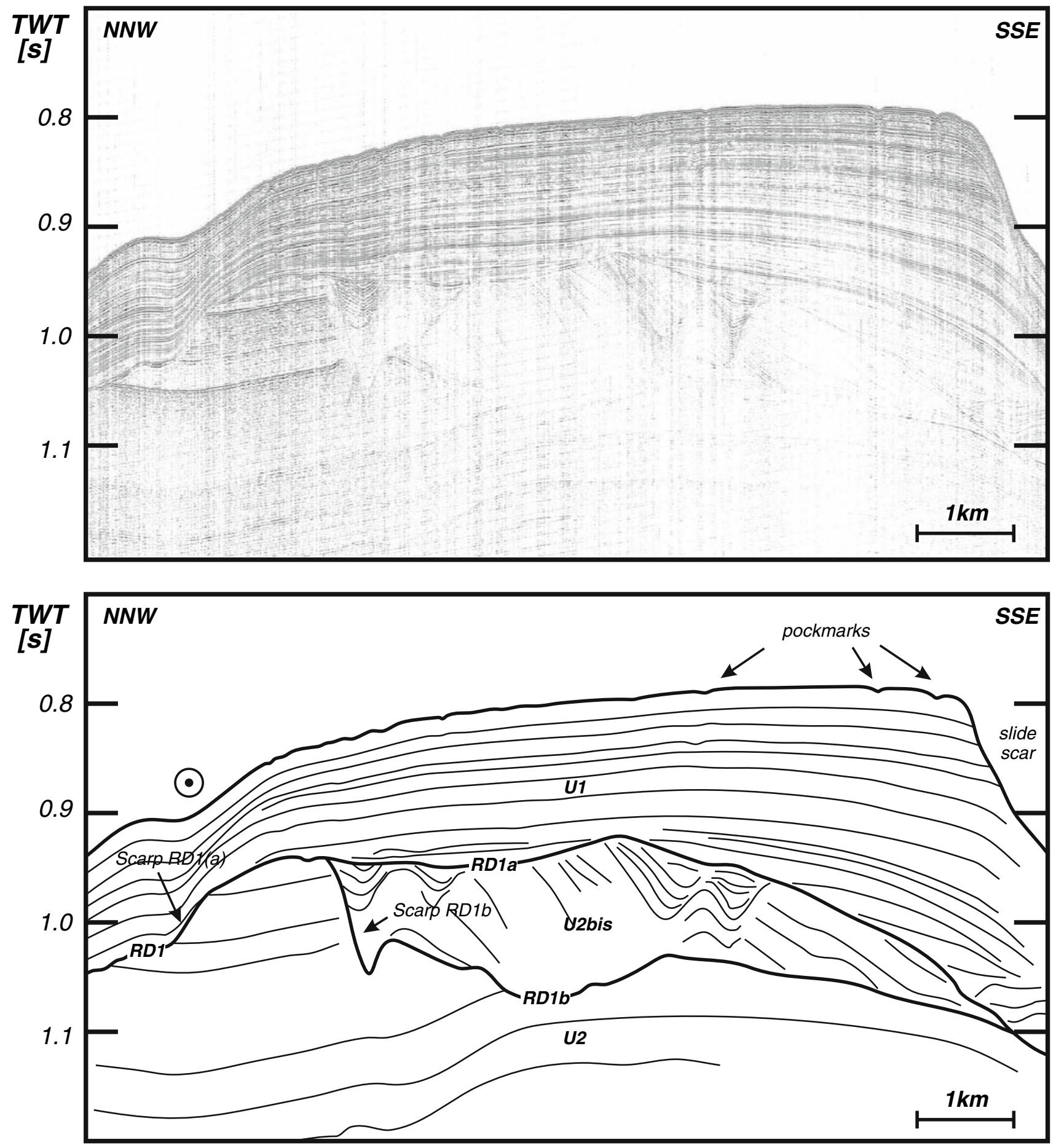

Fig. 4 The NNW-SSE seismic profile P99009a illustrates the upper slope unit U2bis, the erosional scarps and the location of the pockmarks. At the SSE extremity of the profile, near the Kings Channel, a slide scar is observed

It is at this location that the Enya mounds can be observed (Figs. 2c,5,6). They are roughly located between 1 and $2 \mathrm{~km}$ distance of the steep RD1(a) scarp in unit U2. All of the mounds seem to be seated on a topographic irregularity (Figs. 5,6). Up to now, only four Enya mounds have been observed. The largest, most southern one, has a maximum height of $100 \mathrm{~ms}$ TWT $(80 \mathrm{~m})$ and is best documented by the seismic profiles on which it has a maximum width of $810 \mathrm{~m}$ and a minimum width of $400 \mathrm{~m}$ (Figs. 5,6). The three other, smaller Enya mounds are not 


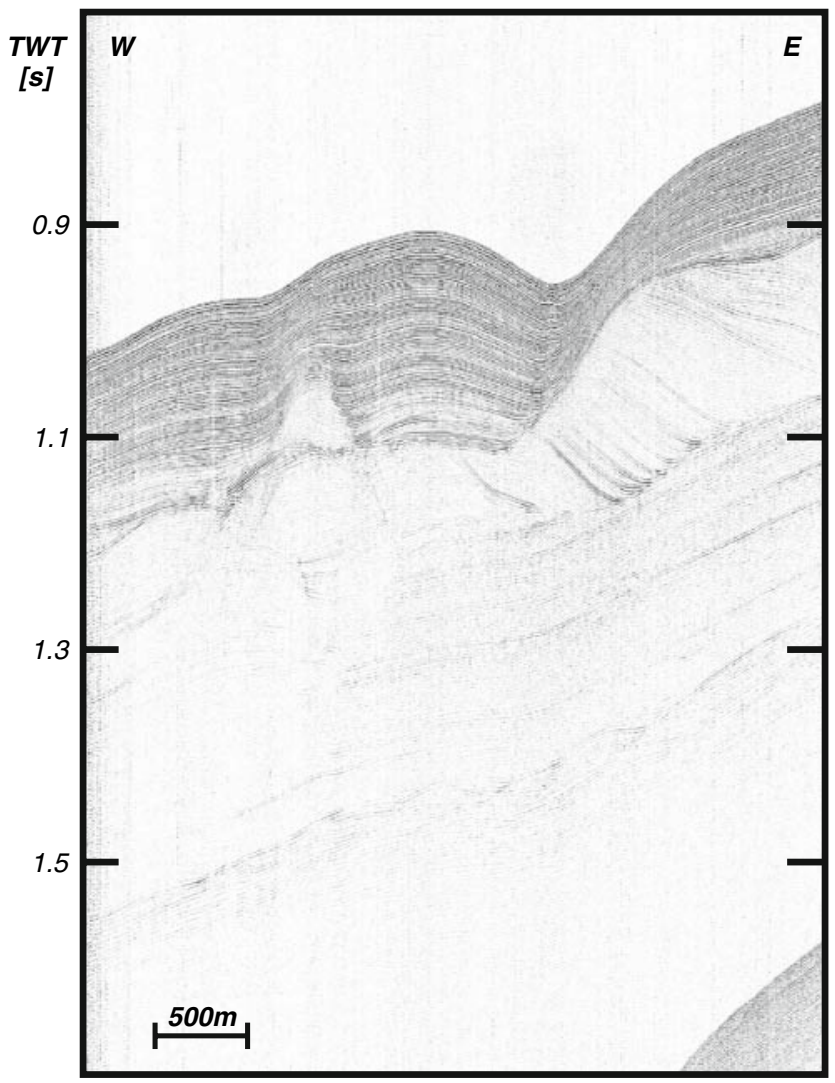

Fig. 5 Seismic profile P030531 (W-E) highlights various aspects of the local stratigraphy, with the coral bank, the contourite drift in the recentmost unit $\mathrm{U} 1$ and indication of the presumed northward flow

higher than $50 \mathrm{~ms}$ TWT $(40 \mathrm{~m})$ and are maximum $400 \mathrm{~m}$ wide (Fig. 6). In size, the Enya mounds are comparable to the average Magellan mounds (Huvenne et al. 2007) and the smallest Belgica mounds (De Mol et al. 2002). Another comparable feature is that they are all buried under 50 120 ms TWT (ca. 40-95 m) of sediment.

\section{Contourite drift deposits}

The recent-most unit U1 displays a seismic facies with predominantly high-amplitude continuous reflectors. Throughout the unit, however, packages with lower amplitudes are observed (Figs. 4,5,6). The geometry of these reflectors is subparallel-sheeted at the eastern side of the study area where it has an average thickness of $100 \mathrm{~ms}$ TWT (Fig. 4). Near the Enya mounds, the geometry becomes elongated mounded, corresponding with the features observed in the present-day bathymetry. This $\mathrm{N}-\mathrm{S}$ elongate mounded sediment body is located in a $1 \mathrm{~km}$ wide passage between the buried coral banks and the U2 scarp and has an axial thickness of $200 \mathrm{~ms}$ TWT $(160 \mathrm{~m})$

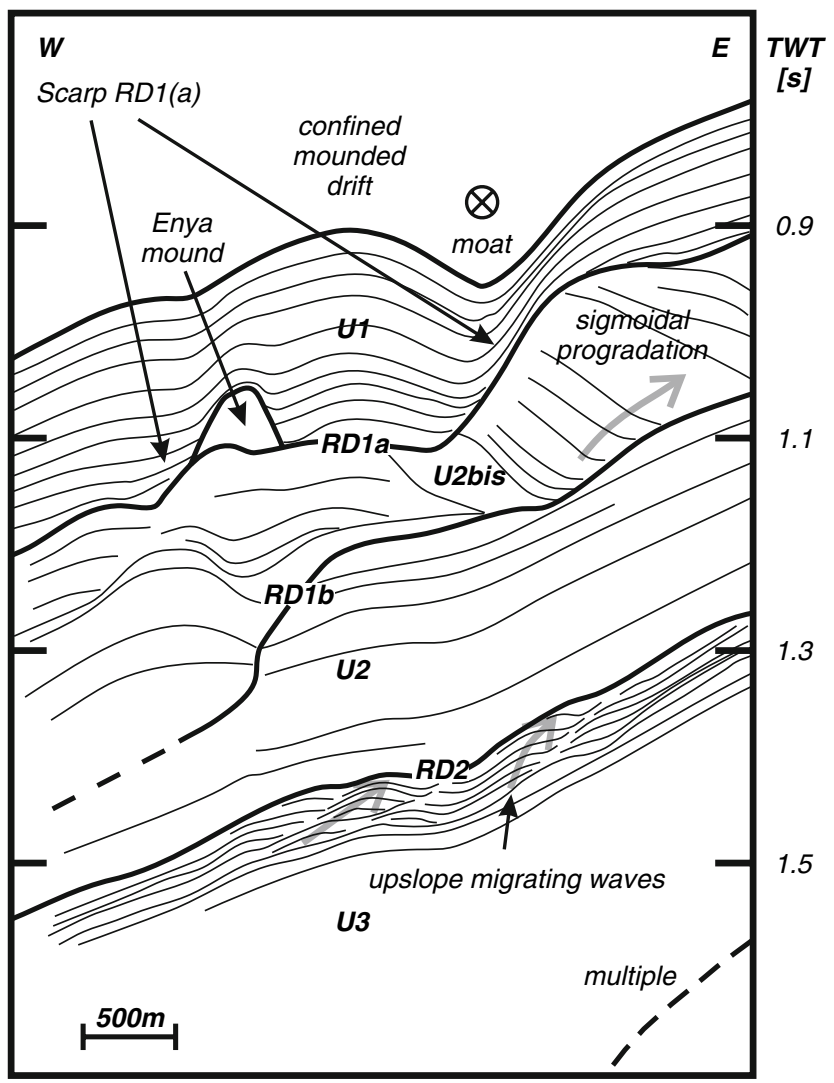

within the moat feature. The lowermost unit features upslope migrating sediment waves, characteristic for this part of the Porcupine Basin

(Fig. 5). The N-S oriented profiles also illustrate gently mounded reflectors in between two mounds (Fig. 6). On W-E profiles, the expression of the present-day moat seems to have increased through time (Fig. 5). On the other hand, the lowermost deposits near the coral bank show a small moat, suggesting the coral bank was already fully developed prior to the deposition of the unit U1. This is also distinctly visible on $\mathrm{N}-\mathrm{S}$ profiles, especially near the northern flank of the large Enya mound (Fig. 6). Around the smaller mound, higher amplitude reflections can be observed near the south flank and above the mound. Most probably, this facies can be interpreted as coarse-grained current-sorted deposits or a hardground. Above the mound, the overlying sediment package shows a convergence of reflectors, suggesting the influence of currents. As such, the entire mounded deposit can be considered to be a smaller variant of a similar mounded confined-elongate contourite drift described within the Belgica mound province (Van Rooij et al. 2007a). Figures 4 and 6 also clearly illustrate the presence of pockmarks near the seabed. They can also be recognized as hyperbolic diffractions below the seabed (Fig. 6), to be interpreted as pockmarks located off the profile track. 

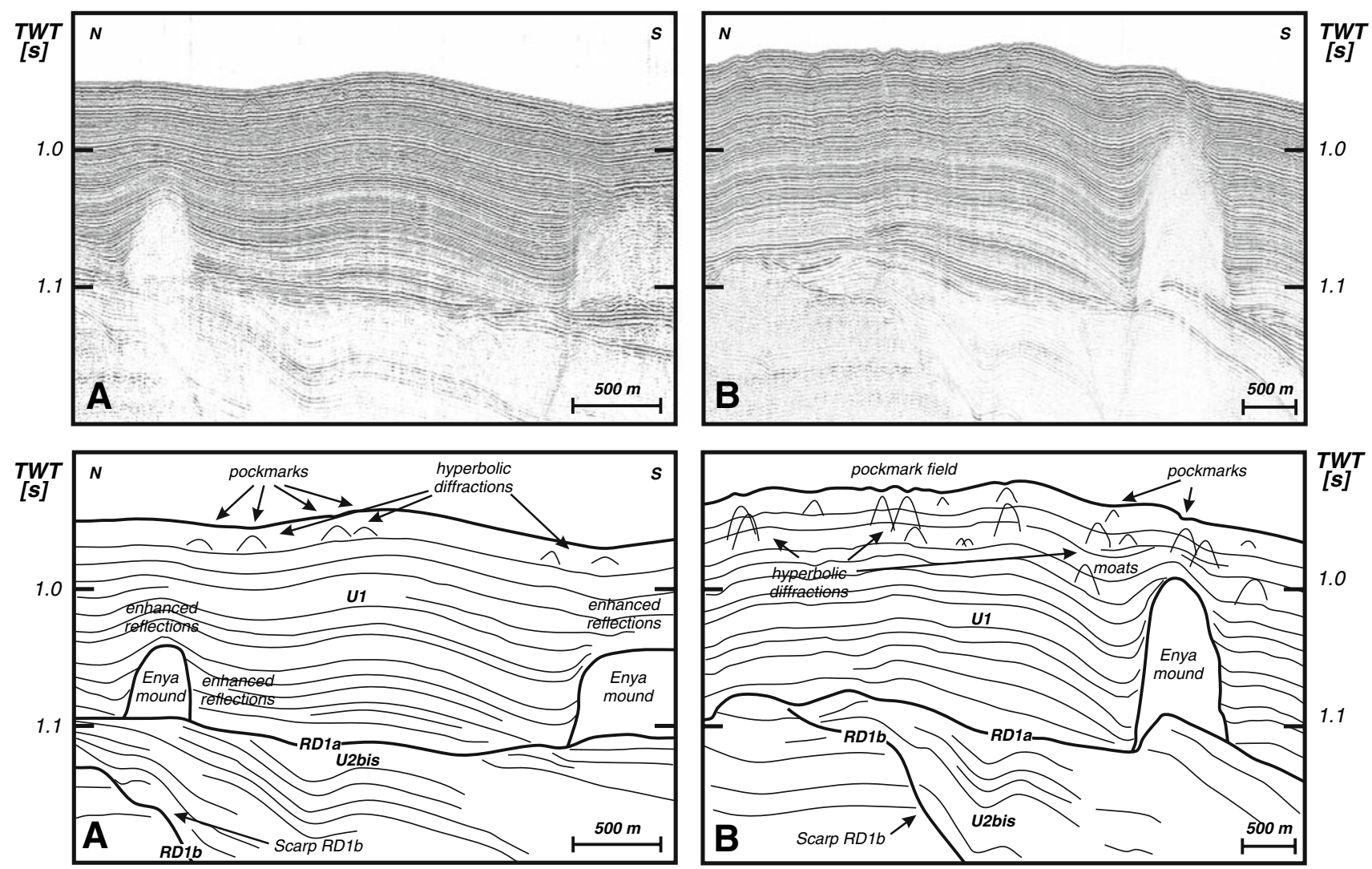

Fig. 6 Seismic profiles P030524 and P030525 illustrates the N-S detail of the area, with respectively two mounds, "enhanced reflectors", pockmarks and moats. The hyperbolic diffractions near the seabed are interpreted as pockmarks located sideways to the profile track

The presence of contourite deposits and their temporal variability is illustrated by the sediment recorded observed in the nearby core MD01-2449 (Figs. 1,3). The top $26 \mathrm{~cm}$ of this core consists of olive clayey very fine quartz-foram sands. This grades downcore into a long and uniform series of olive grey to grey silty clays. Nannofossils and fine sand pockets are commonly observed in varying quantities. Two coarser-grained intervals were also observed; between 600 and $900 \mathrm{~cm}$ and between 1,200 and $1,400 \mathrm{~cm}$. These two intervals are characterized by elevated values of dry bulk density (Fig. 3).

The variations in dry bulk density, mean grainsize, sand content (up to 20\%), magnetic susceptibility and stable $\delta^{18} \mathrm{O}$ isotopes are similar to those of core MD99-2327 (Van Rooij et al. 2007b) and can be used to propose a stratigraphic correlation and time frame (Fig. 3). In both cores a specific peak in magnetic susceptibility occurs at $19 \mathrm{~m}$ in MD01-2449 and at $9 \mathrm{~m}$ in MD99-2327. This peak is followed by a smaller peak in magnetic susceptibility and a decrease in dry bulk density at respectively 17.5 and $8 \mathrm{~m}$. The latter is also associated with a finer mean grain size and a low magnetic susceptibility. Van Rooij et al. (2007b) have correlated this event with HL5 of Auffret et al. (2002) at $45.5 \mathrm{ka}$. Associated to this event, stable $\delta^{18} \mathrm{O}$ isotopes show lighter values, suggesting meltwater input typical for Heinrich events (Auffret et al. 2002; Bond et al. 1992; Cortijo et al. 2005). The associated average sedimentation rates for the interval between the core top and the HL5 event would be $41.8 \mathrm{~cm} \mathrm{ka}^{-1}$ for MD01-2449 and $19.8 \mathrm{~cm} \mathrm{ka}^{-1}$ for MD99-2327.

\section{Discussion}

The following paragraphs will discuss the setting and timing of the Enya mounds growth history with respect to the sedimentary evolution of the eastern Porcupine Seabight. Subsequently, the origin of the pockmarks and their possible relationship with the Enya mound cluster will be evaluated.

Evolutionary stages of the Enya mounds

Timing and nature of the RDI "moundbase" unconformity

Within the Belgica mound province, there has been uncertainty about the true age of the RD1 unconformity 
(De Mol et al. 2002; McDonnell and Shannon 2001; Shannon et al. 2007; Van Rooij et al. 2007a). The downslope transect of the three IODP 307 sites, piercing through this unconformity, has finally given some age constraints for the RD1 unconformity, framed between the Late Miocene and the Late Pliocene (Kano et al. 2007; Louwye et al. 2008). Yet, some questions remained unanswered concerning the actual dynamics and lateral variability of this erosion event. Earlier studies about the lateral variability of the RD1 unconformity have already demonstrated a highly irregular and locally dramatic incision, leaving a terraced landscape, suggesting step-wise erosion phases (Van Rooij et al. 2007a,2003).

At the Enya mound site, the observation of the local RD1b unconformity brings new evidence, strengthening the idea that the 6.6-8.2 long Ma hiatus of RD1 consisted of several phases of erosion and deposition. Most probably, due to the intensity of the last (or second?) RD1a erosion event, unconformity RD1b has been masked elsewhere on the eastern slope of the Porcupine Seabight. The local RD1b unconformity studied here, might document an early phase of erosion within an RD1 composite erosion event, followed by a later stage of a high-energy fill-up (Fig. 4). This scenario may also explain the terraced morphology of the RD1 unconformity in the Belgica mound province and could be more plausible than 6.6-8.2 Ma of continuous erosion.

According to the IODP 307 data, probably no Pliocene clastic sediments are present on the eastern slope of the Porcupine Seabight. Only the base of the coral banks has been dated with a Late Pliocene age (Kano et al. 2007). However, on Goban Spur and adjacent deep-water basins, series of Pliocene clastic deposits were recovered with only a comparatively short Early Pliocene C10 erosion (de Graciansky et al. 1985; Shannon et al. 2007; Stoker et al. 2002; Stoker et al. 2005). Moreover, on the Enya mound site, the seismic profiles recorded probably the thickest (and most complete?) U2 deposits in this region (Figs. 4,5). Therefore, the top of unit U2 at this site can be considered to be at least as old as near IODP site U1318 (Late Miocene), or even younger. It is proposed here that sedimentation continued within the eastern part of the Porcupine Seabight throughout the entire Late Miocene. In such scenario, the Late Miocene deposits were eroded within the Belgica mound province, but were saved near the Enya site. Even if this should not be the case, due to its stratigraphic position, the base of unit U2bis (RD1b) should be younger than the onset of the composite RD1 event as documented in the IODP 307 holes. A later onset of this event might also fit closer to the joint tectonic and oceanographic mechanisms that have caused the $\mathrm{C} 10$ event in the Rockall Trough.

Since the eroded surface is facing the northernmost Kings Channels (Figs. 1,2,4), this small and local RD1b unconformity could very well be documenting a first erosion event that eventually has grown out to become the Kings and Gollum Channels. The nature of the seismic facies of unit U2bis hints at a rapid and chaotic deposition of eroded sediment, during probably the Pliocene. Despite only few profiles in an E-W orientation, the upslope sigmoidal progradation and the complex reflector configuration in Fig. 4 might be documenting the movement of a moat. Although the RD1a erosion could have removed a large part of the upper sediments, unit U2bis shares similarities with contourite drift deposits (Lu et al. 2003; Rebesco et al. 2005; Stow et al. 2002). The presence of post-Middle Miocene contourite drifts has already been suggested by McDonnell and Shannon (2001), but could not be confirmed for the U2 sediments near the Belgica mounds by Van Rooij et al. (2007a). The origin of these sediments might be local, but also more terrigenic since the possible onset of this erosion is linked to the onset of northern hemisphere cooling with lowering sea-levels (Shannon et al. 2007; Stoker et al. 2005).

\section{Enya mound initiation}

In analogy with most of the Belgica mounds (De Mol et al. 2002; Van Rooij et al. 2007a), the Enya mounds are rooted on topographic irregularities of the RD1(a) unconformity. It has been established before that such environments are ideal settling grounds for deep-water corals, provided also the other environmental requirements concerning temperature, salinity, nutrient supply and hydrodynamic regime are met (De Mol et al. 2005; Roberts et al. 2006; Rüggeberg et al. 2007). The studied data can only give some information on the hydrodynamic regime at the time of the start-up of these small mounds.

Following the model of Kenyon et al. (2003), the low number of mounds indicates very high bottom currents with low sediment input at the time of coral settling. Within the present day, this area is influenced by the presence of a focused northward flowing current, associated with enhanced tidal currents through internal waves (Rice et al. 1990; White 2007). The lowermost strata of unit U1 indeed suggest the presence of a strong, probably poleward flowing, bottom current regime at the time of coral bank initiation (Figs. 5,6). First of all, the higher amplitude of the reflections near the RD1(a) moundbase unconformity (Fig. 6) could suggest a coarser facies, winnowed by long periods of strong bottom currents. Secondly, most of the profiles show a distinct moat feature at the base of the drift unit near the coral banks (Figs. 5,6). As in the Belgica mound province (Van Rooij et al. 2007a), this suggests a "junior" mound was already present before the U1 sediments were deposited, inferring high benthic 
currents sweeping the seafloor during the initial phase of mound construction. This lag between an Upper Pliocene coral bank initiation and a surrounding Middle Pleistocene drift sedimentation has already been suggested by De Mol et al. (2002) and Van Rooij et al. (2007a) and has been confirmed by Kano et al. (2007).

The presence of the steep slope in palaeotopography east of the coral banks (Figs. 2,5) might also have induced a local enhancing of the bottom currents. The striking virtual S-N alignment of the Enya mounds at approximately $1 \mathrm{~km}$ distance parallel with this steep scarp, strongly suggests the corals have settled at a location that has profited from a unique hydrodynamic regime (with e.g. enhanced turbidity) fostered by this topographic irregularity. A similar topographic control can be found at the Belgica mound province (De Mol et al. 2002; Van Rooij et al. 2007a) or at the SW Rockall Trough (Kenyon et al. 2003; Mienis et al. 2006).

\section{A burial scenario for the Enya mounds}

During the deposition of unit U1, the Enya mounds have been gradually buried by a small mounded contourite drift. This drift is only a very local feature, bound to the delicate interaction of the hydrography and topography, combined with other variables such as sediment input, palaeoceanographic and hydrodynamic changes. The present seismic and core data of this drift could yield some more information concerning the possible causes and timing of the mound burial.

Certain changes in the Pleistocene palaeoenvironment must have led to a cessation of Enya mound growth. Above, it has been suggested that during mound initiation very high bottom currents with a low sediment load were active. It is assumed that by the Middle Pleistocene the sedimentary environment changed and more sediment was introduced into the basin (Kano et al. 2007; Van Rooij et al. 2007a). This Middle Pleistocene Revolution (MPR, at c. 940-640 ka) is recognized as a global switch from lowamplitude $41 \mathrm{ka}$ obliquity-forced climate cycles to highamplitudes cycles of $100 \mathrm{ka}$, invoking longer glacialinterglacial cycles with associated sea-level falls and rises (Head and Gibbard 2005; Hernandez-Molina et al. 2002; Raymo et al. 1997). In this study area, it would increase the predominant sediment input directly coming from the Irish continental shelf (Rice et al. 1991), with a majority of it being transferred towards and through the Gollum and Kings Channels. Due to the proximity of the Enya mound area near the Kings Channels, it is plausible it has benefited from this focused sediment input and hence shows elevated sedimentation rates in the sedimentary record since the MPR.
This is demonstrated by a comparison of core MD012449 (Kings Channels) with core MD99-2327 (Belgica mound province) (Fig. 3). Although no extensive set of absolute ages is available, specific features recognized in the two cores allowed obtaining sedimentation rates of $41.8 \mathrm{~cm} \mathrm{ka}^{-1}$ for MD01-2449 and $19.8 \mathrm{~cm} \mathrm{ka}^{-1}$ for MD99-2327. Sedimentation rates near the Kings Channels are thus twice as high as the contourite drift sequence in the Belgica mound province. Most of these sediments are finegrained (clay-silt range), as they could have been pirated off suspension clouds from the Kings Channels by the northward flowing currents, leaving coarser material within the channels.

When using these sedimentation rates to estimate the onset of the contourite drift sedimentation in the Enya mound area, a very young age of $382 \mathrm{ka}$ is obtained if extrapolated over the thickest drift deposit (200 ms TWT or $160 \mathrm{~m}$ ). This does not fit at all with the onset of sedimentation in the Belgica mound province, estimated by Van Rooij et al. (2007a) within the MPR at ca. 940-640 ka. However, when comparing thicknesses of the contourite drift packages, the Belgica mound drift seems to be twice as thick (400 ms TWT) as in the Enya mound area $(200 \mathrm{~ms}$ TWT). If the general onset of drift sedimentation on the entire eastern slope is assumed to have initiated at the MPR, this would suggest drastically lower sedimentation rates at the Enya mound site.

Most probably the truth lies between these two extremes with gradually decreasing bottom current strength, increasing sediment input and sedimentation rates starting from the Middle Pleistocene. In the first stage of contourite deposition, starting at about the MPR, the drift seemed to cope with the coral bank growth. At that time, bottom currents might still have been stronger, as evidenced by the presence of moats and enhanced reflectors indicating possible coarser sediments. These initial strong bottom currents could have prevented high sedimentation rates. Due to a possibly gradual reduction in current strength, sedimentation rates increased and literally started to overcloud the Enya mounds; the sediments started to onlap the mounds, until they eventually draped across the mound structures. An almost identical scenario has been proposed for the Magellan mounds by Huvenne et al. (2007). All along the NW European margin, coral banks are being buried whenever the current strength decreases and sedimentation rates become too high (Huvenne et al. 2003; Kenyon et al. 2003; Mienis et al. 2006).

Nature and timing of fluid seepage

The sidescan sonar data and seismic imagery show the presence of a relatively large pockmark field associated 
with the Enya mound cluster. At first sight, they only seem to be linked to unit U2bis, as $89 \%$ of the pockmarks are located above this deposit (Fig. 2c). Most of the pockmarks are located at the southeastern extremity of the study area. It is at least remarkable that also the coral banks are rooted above unit U2bis, which could suggest a relationship with fluid seepage. A similar relationship was proposed by Henriet et al. (2001) for the Hovland and Magellan mound provinces, where De Mol et al. (2002) and Huvenne et al. (2007) also described the presence of coral banks above a similar facies.

Pockmarks are formed under the action of upward fluid flow through fine-grained sediments. This is commonly related to overpressured biogenic gas, thermogenic gas or pore water. Their dimensions vary between 15 and $850 \mathrm{~m}$ width and 1-45 $\mathrm{m}$ depth, according to which the Enya pockmarks would be classified as average in size (Gay et al. 2006; Hovland et al. 2002; Hovland and Judd 1988; Jensen et al. 2002; Paull et al. 2002; Schroot et al. 2005).

Most pockmark clusters are observed near large hydrocarbon provinces. They are commonly associated with gas plumes, columnar disturbances or "chimneys", acoustic blanking and "bright spots". These features indicate the presence of interstitial gas within the sediment or local high concentrations of free gas (Casas et al. 2003; Paull et al. 2002; Schroot et al. 2005; Van Rensbergen et al. 2007). Although Croker and Shannon (1995) and Johnston et al. (2001) inferred the presence of possible reservoirs in Permo-Triassic sandstones, none of the above migration features have been observed on the seismic profiles. Moreover, the possibility to generate seepage from these yet uncharted reservoirs seems to be very speculative (Shannon, pers. comm.).

Another possible source for overpressured fluids in this area might be found in the unit U2bis. The nature of these deposits suggests a dynamic environment where sands or silts are rapidly deposited. A quick burial by muddy sediments could cause overpressure of pore water and/or possibly biogenic gas (Hovland et al. 2002; Paull et al. 2002). A similar process was described by Masson et al. (2003) where the escape of pore water from buried sediments was suggested to be the main agent of pockmark formation close to the Darwin mound area. Nevertheless, no evidence is found of past fluid flow such as breached surfaces or deformations in the sediments overlying U2bis. As such, also a relatively shallow origin for these pockmarks is highly speculative.

In either two cases, the timing and periodicity of the fluid seepage is important to assess any relationship with the coral banks. The seismic profiles only show pockmark features near the seafloor. In the absence of the typical manifestations of free gas in the sediment column, buried pockmarks might be the only evidence of past fluid seepage
(Baraza and Ercilla 1996; Casas et al. 2003; Van Rensbergen et al. 2007). However, no evidence is found of earlier, buried pockmarks. This suggests the Enya pockmarks are relatively recent features, possibly generated during the last sealevel lowstand during the Last Glacial Maximum.

Seen the relatively recent timing of the seepage, the inferred spatial relationship between the pockmarks and unit U2bis or the Enya mounds seems to be purely coincidental. Neither a deep nor a shallow source for the seepage could be indicated.

\section{Conclusion}

The local seismic stratigraphy of the Enya mound cluster has revealed some new elements that might shed new light on the Neogene margin development of the Porcupine Seabight. The presence of a previously unmapped unconformity suggests that the Late Miocene to Late Pliocene $\mathrm{RD} 1$ "moundbase" unconformity is a composite event that has been active in at least two phases, locally recognized as $\mathrm{RD} 1 \mathrm{~b}$ and RD1a, possibly in alternation with small depositional phases. It is suggested that the onset of this composite RD1 erosion event might have started at a later period within the Late Miocene. As such, a Pliocene contourite drift unit U2bis was deposited on a presumed Late Miocene RD1b unconformity. Large parts of this deposit were removed during a last (Intra-Pliocene) RD1a event, also masking most of the RD1b unconformity throughout this part of the slope. This scenario would be more in accordance with the Late Cenozoic stratigraphic framework as suggested by Shannon et al. (2007) and Stoker et al. (2005). This multi-phased erosion created the terraced morphology of the Belgica mound province, but also cut the upper slope pathway for the Kings and Gollum Channels.

Subsequent to the RD1a event, corals began to colonize topographic irregularities during the Upper Pliocene. The coral banks were built in a period when the adjacent areas experienced non-deposition through a relatively high bottom current regime. They are located in a zone which experienced a complex interaction of enhanced currents with a steep S-N scarp in the palaeotopography. As such, a limited number of coral banks were formed parallel to the slope scarp. From the Middle Pleistocene onwards, increasing sediment input and a lowered velocity of the bottom currents gradually increased the sedimentation rate, slowly burying the Enya mounds under a small mounded contourite drift, similar to those described by Van Rooij et al. (2007a) in the Belgica mound province.

The presence of a pockmark field on the present-day seabed could not be related to a deep or a shallow origin. 
Since no further geophysical evidence was found of typical seepage features, it is concluded that the pockmarks are relatively recent. Hence, no relationship can be found with the presence of the coral banks and more research will be needed to reveal the causal mechanism of these pockmarks.

This study has shown that, as most of the NW European coral banks, the Enya mound cluster experienced a substantial environmental control by currents, topography and sediment input.

Acknowledgements The authors would like to acknowledge the captains, crews and shipboard parties of R/V Belgica, R/V Polarstern, R/V Pelagia and R/V Marion Dufresne. The study of the Enya mounds originated during the EC FP5 "Geomound" project and was respectively continued under EC FP5 RTN EURODOM and EC FP6 HERMES (contract GOCE-CT-2005-511234-1). The TOBI data was collected within the framework of a project undertaken with support of the European Union (EASSS III programme, 'Improving Human Potential', contract HPRI-CT-1999-00047) and on behalf of the Porcupine Studies Group (PSG) of the Irish Petroleum Infrastructure Programme Group 3. The PSG comprises: Agip Ireland BV, Chevron UK Ltd., Elf Petroleum Ireland BV, Enterprise Energy Ireland Ltd., Marathon International Hibernia Ltd., Philips Petroleum Company United Kingdom Ltd., Statoil Exploration (Ireland) Ltd. and the Petroleum Affairs Division of the Department of the Communication, Marine and Natural Resources. We would also like to thank G. Isguder, F. Dewilde and F. Manssouri at LSCE, Gif-surYvette (FR) for the isotopic analysis of core MD01-2449. Also M. Vinckx and D. Schram of the Ghent University Marine Biology section are acknowledged for the use of the Coulter LS130. Swell filtering of the seismic profiles was performed using Swellfilter.com developed by P. Staelens. We also appreciated the comments and suggestions of the topic editor, M. Rebesco and an anonymous reviewer, which significantly improved the quality of this manuscript. DVR is a post-doctoral fellow of the FWO-Flanders. VH is a Marie-Curie post-doctoral fellow and honorary fellow of FWOFlanders.

\section{References}

Auffret GA, Zaragosi S, Dennielou B, Cortijo E, Van Rooij D, Grousset FE, Pujol C, Eynaud F, Siegert M (2002) Terrigenous fluxes at the Celtic margin during the last glacial cycle. Mar Geol 188:79-108

Bailey W, Shannon PM, Walsh JJ, Unnithan V (2003) The spatial distributions of faults and deep sea carbonate mounds in the Porcupine Basin, offshore Ireland. Mar Petrol Geol 20:509-522

Baraza J, Ercilla G (1996) Gas-charged sediments and large pockmark-like features on the Gulf of Cadiz slope (SW Spain). Mar Petrol Geol 13:253-261

Beyer A, Chackraborty B, Schenke HW (2007) Seafloor classification of the mound and channel provinces of the Porcupine Seabight: an application of the multibeam angular backscatter data. Int J Earth Sci 96:11-20. doi:10.1007/s00531-005-0022-1

Beyer A, Schenke HW, Klenke M, Niederjasper F (2003) High resolution bathymetry of the eastern slope of the Porcupine Seabight. Mar Geol 198:27-54

Bond G, Heinrich $\mathrm{H}$, Broecker WS, Labeyrie LD, McManus J, Andrews JT, Huon S, Jantschik R, Clasen S, Simet C, Tedesco K, Klas M, Bonani G, Ivy S (1992) Evidence for massive discharges of icebergs into the North Atlantic ocean during the last glacial period. Nature 360:245-249
Casas D, Ercilla G, Baraza J (2003) Acoustic evidences of gas in the continental slope sediments of the Gulf of Cadiz (E Atlantic). Geomar Lett 23:300-310

Cortijo E, Duplessy JC, Labeyrie L, Duprat J, Paillard D (2005) Heinrich events: hydrological impact. C.R. Acad Sci Paris série IIa 337:897-907

Croker PF, Shannon PM (1995) The petroleum geology of Ireland's offshore basins. Geological Society, London, p 498

de Graciansky PC, Poag CW, Cunningham R, Loubere P, Masson DG, Mazzullo JM, Montadert L, Müller C, Otsuka K, Reynolds LA, Sigal J, Snyder SW, Townsend HA, Vaos SP, Waples D (1985) The Goban Spur transect: geologic evolution of a sediment-starved passive continental margin. Geol Soc Am Bull 96:58-76

De Mol B, Henriet J-P, Canals M (2005) Development of coral banks in Porcupine Seabight: do they have Mediterranean ancestors? In: Freiwald A, Murray Roberts J (eds) Cold-water corals and ecosystems. Springer, Berlin, Heidelberg, pp 515-533

De Mol B, Kozachenko M, Wheeler AJ, Alvares H, Henriet J-P, OluLe Roy K (2007) Thérèse Mound: a case study of coral bank development in the Belgica Mound Province, Porcupine Seabight. Int J Earth Sci 96:103-120. doi:10.1007/s00531-0050496-x

De Mol B, Van Rensbergen P, Pillen S, Van Herreweghe K, Van Rooij D, McDonnell A, Huvenne V, Ivanov M, Swennen R, Henriet J-P (2002) Large deep-water coral banks in the Porcupine Basin, southwest of Ireland. Mar Geol 188:193-231

Foubert A, Beck T, Wheeler AJ, Opderbecke J, Grehan A, Klages M, Thiede J, Henriet J-P, the Polarstern ARK-XIX/3a shipboard party (2005) New view of the Belgica Mounds, Porcupine Seabight, NE Atlantic: preliminary results from the Polarstern ARK-XIX/3a ROV cruise. In: Freiwald A, Roberts JM (eds) Deep-water corals and ecosystems. Springer, Heidelberg, pp 403-415

Gay A, Lopez M, Ondreas H, Charlou J-L, Sermondadaz G, Cochonat P (2006) Seafloor facies related to upward methane flux within a Giant Pockmark of the Lower Congo Basin. Mar Geol 226:81-95

Hargreaves PM (1984) The distribution of Decapoda (Crustacea) in the open ocean and near-bottom over an adjacent slope in the northern North-East Atlantic Ocean during Autumn 1979. J Mar Biol Assoc UK 64:829-857

Head MJ, Gibbard PL (2005) Early-middle Pleistocene transitions: an overview and recommendation for the defining boundary. In: Head MJ, Gibbard PL (eds) Early-middle Pleistocene transitions: the land-ocean evidence. Geological Society, London, Special Publications 247, pp 1-18

Henriet J-P, De Mol B, Pillen S, Vanneste M, Van Rooij D, Versteeg W, Croker PF, Shannon PM, Unnithan V, Bouriak S, Chachkine P, The Porcupine-Belgica 97 Shipboard Party (1998) Gas hydrate crystals may help build reefs. Nature 391:648-649

Henriet J-P, De Mol B, Vanneste M, Huvenne V, Van Rooij D, the "Porcupine-Belgica" '97 '98 and '99 shipboard parties (2001) Carbonate mounds and slope failures in the Porcupine Basin: a development model involving past fluid venting. In: Shannon PM, Haughton P, Corcoran D (eds) The petroleum exploration of Ireland's offshore basins. Geological Society, London, Special Publication 188, pp 375-383

Hernandez-Molina FJ, Somoza L, Vazquez JT, Lobo F, FernandezPuga MC, Llave E, Diaz-del Rio V (2002) Quaternary stratigraphic stacking patterns on the continental shelves of the southern Iberian Peninsula: their relationship with global climate and palaeoceanographic changes. Quaternary Int 92:5-23

Hovland M, Croker PF, Martin M (1994) Fault-associated seabed mounds (carbonate knolls?) off western Ireland and north-west Australia. Mar Petrol Geol 11:232-246 
Hovland M, Gardner JV, Judd AG (2002) The significance of pockmarks to understanding fluid flow processes and geohazards. Geofluids 2:127-136. doi:10.1046/j.1468-8123.2002. 00028.x

Hovland M, Judd AG (1988) Seabed pockmarks and seepages, impact on geology, biology and the environment. Graham \& Trotman, London, p 293

Hovland M, Risk M (2003) Do Norwegian deep-water coral reefs rely on seeping fluids? Mar Geol 198:83-96

Huvenne VAI, Bailey WR, Shannon PM, Naeth J, di Primio R, Henriet J-P, Horsfield B, de Haas H, Wheeler AJ, Olu-Le Roy K (2007) The Magellan mound province in the Porcupine Basin. Int J Earth Sci 96:85-101. doi:10.1007/s00531-005-0494-z

Huvenne VAI, De Mol B, Henriet J-P (2003) A 3D seismic study of the morphology and spatial distribution of buried coral banks in the Porcupine Basin, SW of Ireland. Mar Geol 198:5-25

IODP 307 Expedition Scientists (2005) Modern carbonate mounds: porcupine drilling. IODP Prel Rept 307. doi:10.2204/iodp. pr.307.2005

Jensen JB, Kuijpers A, Bennike O, Laier T, Werner F (2002) New geological aspects for freshwater seepage and formation in Eckernförde Bay, western Baltic. Cont Shelf Res 22:2159-2173

Johnston S, Doré AG, Spencer AM (2001) The Mesozoic evolution of the southern North Atlantic region and its relationship to basin development in the south Porcupine Basin, offshore Ireland. In: Shannon PM, Haughton P, Corcoran D (eds) The petroleum exploration of Ireland's offshore basins. Geological Society, London, Special Publication 188, pp 237-263

Kano A, Ferdelman TG, Williams T, Henriet JP, Ishikawa T, Kawagoe N, Abe K, Sakai S, Browning E, Li X, the IODP Expedition 307 Scientists (2007) Age constraints on the origin and growth history of a deep-water coral mound in NE Atlantic drilled in IODP Expedition 307. Geology 35:1051-1054. doi: 10.1130/G23917A.1

Kenyon NH, Akhmetzhanov AM, Wheeler AJ, van Weering TCE, de Haas H, Ivanov MK (2003) Giant carbonate mud mounds in the southern Rockall Trough. Mar Geol 195:5-30

Kenyon NH, Belderson RH, Stride AH (1978) Channels, canyons and slump folds between South-West Ireland and Spain. Oceanol Acta 1:369-380

Le Bas T, Hühnerbach V (1999) P.R.I.S.M. processing of remotelysensed imagery for seafloor mapping operators manual version 3.1. Southampton Oceanographic Centre, UK

Lindberg B, Berndt C, Mienert J (2007) The Fugloy Reef at $70^{\circ} \mathrm{N}$; acoustic signature, geologic, geomorphologic and oceanographic setting. Int J Earth Sci 96:201-213. doi:10.1007/s00531-0050495-y

Louwye S, Foubert A, Mertens K, Van Rooij D, the IODP Exp. 307 Scientific Party (2008) Integrated stratigraphy and palaeoecology of the lower and middle Miocene of porcupine basin. Geol Mag. doi:10.1017/S0016756807004244

Lu H, Fulthorpe CS, Mann P (2003) Three-dimensional architecture of shelf-building sediment drifts in the offshore Canterbury Basin, New Zealand. Mar Geol 193:19-47

Masson DG, Bett BJ, Billet DSM, Jacobs CL, Wheeler AJ, Wynn RB (2003) The origin of deep-water, coral-topped mounds in the northern Rockall Trough, Northeast Atlantic. Mar Geol 194:159-180

McDonnell A, Shannon PM (2001) Comparative Tertiary stratigraphic evolution of the Porcupine and Rockall basins. In: Shannon PM, Haughton P, Corcoran D (eds) The petroleum exploration of Ireland's offshore basins. Geological Society, London, Special Publication 188, pp 323-344

Mienis F, van Weering T, de Haas H, de Stigter H, Huvenne V, Wheeler A (2006) Carbonate mound development at the SW
Rockall Trough margin based on high resolution TOBI and seismic recording. Mar Geol 233:1-19

Naeth J, di Primio R, Horsfield B, Schaefer RG, Shannon PM, Bailey WR, Henriet JP (2005) Hydrocarbon seepage and carbonate mound formation: a basin modelling study from the porcupine basin (offshore Ireland). J Petrol Geol 28:147-165

New AL, Barnard S, Herrmann P, Molines J-M (2001) On the origin and pathway of the saline inflow to the Nordic Seas: insights from models. Prog Oceanog 48:255-287

O'Reilly BM, Readman PW, Shannon PM, Jacob AWB (2003) A model for the development of a carbonate mound population in the Rockall Trough based on deep-towed sidescan sonar data. Mar Geol 198:55-66

Paull C, Ussler W III, Maher N, Rehder G, Lorenson T, Lee H (2002) Pockmarks off Big Sur, California. Mar Geol 181:323-335

Raymo ME, Oppo D, Curry WB (1997) The mid-Pleistocene climate transition: a deep sea carbon isotopic perspective. Paleoceanography $12: 546-559$

Rebesco M (2005) SEDIMENTARY ENVIRONMENTS । Contourites. In: Selley RC, Cocks LRM, Plimer IR (eds) Encyclopedia of geology. Elsevier, Oxford, pp 513-528

Rice AL, Billet DSM, Thurston MH, Lampitt RS (1991) The institute of oceanographic sciences biology programme in the porcupine Seabight: background and general introduction. J Mar Biol Assoc UK 71:281-310

Rice AL, Thurston MH, New AL (1990) Dense aggregations of a hexactinellid sponge, Pheromena carpenteri, in the Porcupine Seabight (northeast Atlantic Ocean), and possible causes. Prog Oceanog 24:179-196

Roberts JM, Wheeler AJ, Freiwald A (2006) Reefs of the deep: the biology and geology of cold-water coral ecosystems. Science 312:543-547

Rüggeberg A, Dullo C, Dorschel B, Hebbeln D (2007) Environmental changes and growth history of a cold-water carbonate mound (Propeller Mound, Porcupine Seabight). Int J Earth Sci 96:5772. doi:10.1007/s00531-005-0504-1

Schroot BM, Klaver GT, Schüttenhelm RTE (2005) Surface and subsurface expressions of gas seepage to the seabed-examples from the Southern North Sea. Mar Petrol Geol 22:499-515

Shannon PM (1991) The development of Irish offshore sedimentary basins. J Geol Soc Lond 148:181-189

Shannon PM, McDonnell A, Bailey W (2007) The evolution of the Porcupine and Rockall basins, offshore Ireland: the geological template for carbonate mound development. Int J Earth Sci 96:21-35. doi:10.1007/s00531-006-0081-y

Stoker MS, Nielsen T, van Weering TCE, Kuijpers A (2002) Towards an understanding of the Neogene tectonostratigraphic framework of the NE Atlantic margin between Ireland and the Faroe Islands. Mar Geol 188:233-248

Stoker MS, Praeg D, Hjelstuen BO, Laberg JS, Nielsen T, Shannon PM (2005) Neogene stratigraphy and the sedimentary and oceanographic development of the NW European Atlantic margin. Mar Petrol Geol 22:977-1005

Stoker MS, van Weering TCE, Svaerdborg T (2001) A mid- to late Cenozoic tectonostratigraphic framework for the Rockall Trough. In: Shannon PM, Haughton P, Corcoran D (eds) Petroleum exploration of Ireland's offshore basins. Geological Society, London, Special Publication 188, pp 411-438

Stow DAV, Faugères J-C, Howe JA, Pudsey CJ, Viana AR (2002) Bottom currents, contourites and deep-sea sediment drifts: current state-of-the-art. In: Stow DAV, Pudsey CJ, Howe JA, Faugères J-C, Viana AR (eds) Deep-water contourite systems: modern drifts and ancient series, seismic and sedimentary characteristics. Geological Society, London, Memoirs 22, pp $7-20$ 
Van Rensbergen P, Rabaute A, Colpaert A, St. Ghislain T, Mathijs M, Bruggeman A (2007) Fluid migration and fluid seepage in the Connemara Field, Porcupine Basin interpreted from industrial 3D seismic and well data combined with high-resolution site survey data. Int J Earth Sci 96:185-197. doi:10.1007/s00531005-0021-2

Van Rooij D (2004) An integrated study of Quaternary sedimentary processes on the eastern slope of the Porcupine Seabight, SW of Ireland. Unpublished Ph.D. thesis, Ghent University, Ghent, $\mathrm{p}$ 330

Van Rooij D, Blamart D, Kozachenko M, Henriet J-P (2007a) Small mounded contourite drifts associated with deep-water coral banks, Porcupine Seabight, NE Atlantic Ocean. In: Viana AR, Rebesco M (eds) Economic and palaeoceanographic importance of contourite deposits. Geological Society, London, Special Publication 276, pp 225-244

Van Rooij D, Blamart D, Richter TO, Wheeler AJ, Kozachenko M, Henriet J-P (2007b) Quaternary sediment dynamics in the Belgica mounds province, Porcupine Seabight: ice rafting events and contour current processes. Int J Earth Sci 96:121-140. doi: 10.1007/s00531-006-0086-6

Van Rooij D, De Mol B, Huvenne V, Ivanov MK, Henriet J-P (2003) Seismic evidence of current-controlled sedimentation in the
Belgica mound province, upper Porcupine slope, southwest of Ireland. Mar Geol 195:31-53

van Weering TCE, de Haas H, de Stigter HC, Lykke-Andersen H, Kouvaev I (2003) Structure and development of giant carbonate mounds at the SW and SE Rockall Trough margins, NE Atlantic Ocean. Mar Geol 198:67-81

Wheeler AJ, Beyer A, Freiwald A, de Haas H, Huvenne VAI, Kozachenko M, Olu-Le Roy K, Opderbecke J (2007) Morphology and environment of cold-water coral carbonate mounds on the NW European margin. Int J Earth Sci 96:37-56. doi: 10.1007/s00531-006-0130-6

Wheeler AJ, Kenyon NH, Ivanov MK, Beyer A, Cronin B, McDonnell A, Schenke HW, Akhmetzhanov AM, Satur N, Zaragosi S (2003) Canyon heads and channel architecture of the Gollum channel, porcupine seabight. In: Mienert J, Weaver PPE (eds) European margin sediment dynamics: side-scan sonar and seismic images. Springer, Heidelberg, pp 183-186

White M (2007) Benthic dynamics at the carbonate mound regions of the Porcupine Sea Bight continental margin. Int J Earth Sci 96:19. doi:10.1007/s00531-006-0099-1 